\title{
Assessment of Free Flow Baffle Wall Constructed Wetland (BWCW) For Treating Wastewater Discharges from Fish Culture Ponds in Kolleru Area
}

\author{
P. Ravindra Nadh, K.V.S.G. Murali Krishna, K.B. Reddy
}

\begin{abstract}
Kolleru Lake is one of the largest fresh water bodies among the Indian wetlands. It is located in the West Godavari and Krishna districts of Andhra Pradesh, India. The lake receives water from 13 major streams/ rivulets. Among them Tammileru and Budameru are important in terms of water input. Indiscriminate exploitation of the Kolleru area has evidently resulted in depletion of many of the ecological goods and services conventionally derived from it. The major sources of pollution are agricultural run-off carries residues of several agrochemicals such as fertilizers, pesticides and herbicides; fish tank discharges contain antibiotics, pro-biotics and food wastes; industrial effluents containing chemical residues and organics of different types and municipal and domestic sewage of high BOD. As a part of Environmental Management Plan of Kolleru Lake a study was carried out to identify a low cost, environment friendly and sustainable non-conventional treatment option for aquaculture wastewater discharges from fish ponds which are a pre-dominant along the inlet drains near the mouth of Kolleru Lake. Constructed or engineered wetland is a proven and sustainable technological intervention to deal with low to moderate pollution loads. According to India water portal, constructed wetlands are cost-effective cleaning option. A Free Flow Baffle Wall Constructed Wetland (BWCW) was designed and fabricated with two units for testing two different macrophytes i.e., Eichhornia crassipes in Unit I and Typha angustata in Unit II to treat the wastewater samples collected from fish pond discharges joining the inlet drains of Kolleru Lake. Wastewater samples were collected during four different seasons of the year and applied for treatment in Unit I and II of BWCW to determine the potential of the macrophytes in treating the wastewater. The study revealed that the concentrations of tested parameters in treated waters of Unit I and Unit II varied from season to season with encouraging treatment efficiencies for treating the wastewater discharges from fish ponds.
\end{abstract}

Index Terms - Baffle wall constructed wetland, Fishpond discharge, Macrophytes, Kolleru area

\section{INTRODUCTION}

Water availability is facing many challenges globally especially in developing countries such as improper water management, reduction of surface and groundwater resources.

P. Ravindra Nadh, Senior Environmental Engineer, A.P. Pollution Control Board, Visakhapatnam

K.V.S.G. Murali Krishna, Professor, Department of Civil Engineering, JNTU Kakinada, Kakinada, Andhra Pradesh.

K.B. Reddy, Professor (Retd), Department of Environmental Science, Acharya Nagarjuna University, Guntur.
Competition for water has widely increased as it has become difficult to satisfy the requirements of water supply for human consumption, food production, ecosystems, and other uses. As a result, net freshwater resources on earth have not only been dwindling exponentially, but also turning perilous at an alarming pace to humans [1, 2] and all other life forms [3]. In the light of this gravitas, strategies to ensure rational use of water resources, especially in our country are urgently called for without any second thought. Wetlands are one of the most productive ecosystems of the world offering wide range of eco-services like water purification, ground water recharge, stream flow maintenance, flood balancing, nutrient recycling, wildlife habitats, natural food resources, food chain support,

aquatic life form sustenance and a host of other benefits including carbon sequestration. Kolleru Lake is a fresh water wet land lying between latitudes $16^{\circ} 32^{\prime}-16^{\circ} 51^{\prime}$ and longitudes $81^{\circ} 50^{\prime}-81^{\circ} 20^{\prime}$ in the districts of West Godavari and Krishna in-between the two major rivers Godavari and Krishna in Andhra Pradesh, India. The lake was declared as a Wildlife Sanctuary in 1999 under the Indian Wildlife Protection Act, 1972 and an internationally important Ramsar Site on 19th August 2002 [4]. About 9.6 TMC of freshwater is estimated to reach the lake from all the sources. The inflow in peak rainy season is about $1,11,000$ cusec while the out flow is a meager 12,000 cusec [5]. The lake discharges into the Bay of Bengal in the east through a meandering $65 \mathrm{~km}$ long channel called Upputeru. Fertilizers, pesticides and their residues from agriculture activities; antibiotics, nutrients and fish feed residues from aquaculture practices; effluents (inorganics,

organics and metals) and wastewater from industrial

establishments and domestic wastes and sewage from adjoining towns such as Eluru, Gudivada and Vijayawada in the catchment area reach the lake in unabated manner turning almost the entire water body into a highly polluted environ pathetically [6]. Fish tank discharges containing high organic load, chemical fertilizers, pesticides and residual feeds also reach the lake. In order to enhance plankton production in fish farms, hundreds of tonnes of phosphate, nitrate, farmyard manure, etc. are put to the tanks. Of this, fertilizer application alone was put at 1200 metric tonnes per year. Usage of such huge amounts of inorganic/ organic chemical supplements leads to accumulation, especially of phosphates in the soil because of their high affinity to bind with soil. This in turn leads to algal proliferation and subsequent eutrophication further to enormous multiplication of bacteria that play a 
crucial role in decomposing organic matter. All this leads to rapid consumption of DO making the inlet waters deficient of the vital life gas essential to all aquatic life.

The surrounding areas of Kolleru Lake form a conducive environment for aquatic life. The lake area was free from aquaculture pollution prior to 1970's [7] reported that Kolleru Lake is vanishing through large scale encroachment of illegal fishponds, and there was no trace of clear water in the lake as per 2001 land use classification. The Government of Andhra Pradesh has taken up "Operation Kolleru” in 2006 to protect the lake ecosystem and its functions and services, by dismantling the fishponds across this region. The land use maps showing the status of Kolleru Lake below $1.52 \mathrm{~m}$ contur level in 2018 was documented [8] and are shown in Fig 1 \& 2.

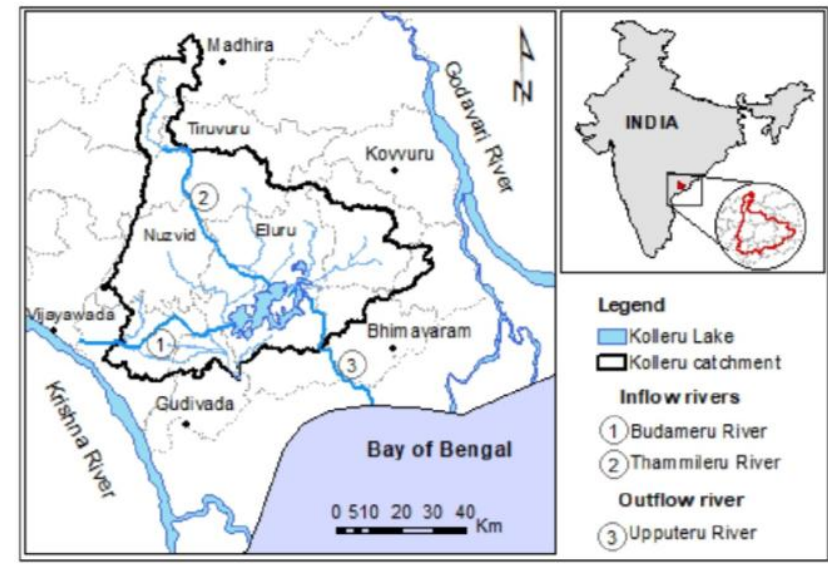

Fig. 1 Location of Kolleru lake [8]

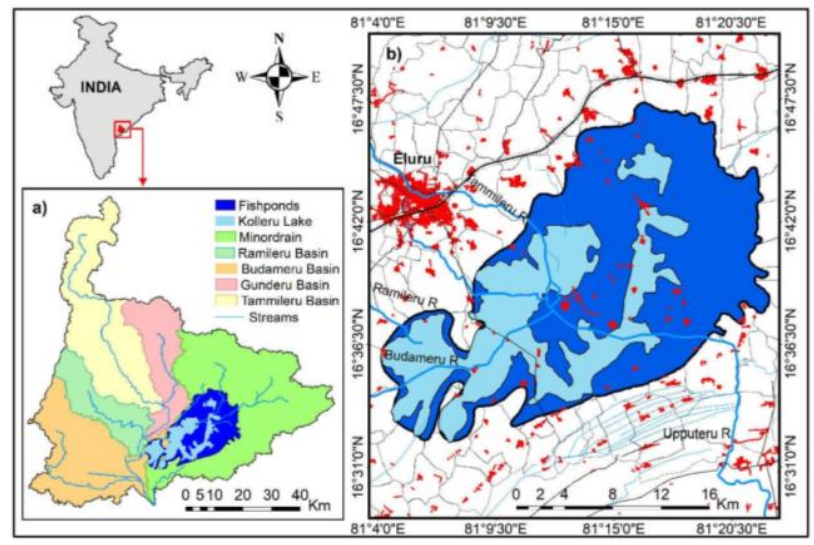

Fig. 2 Geographical map of Kolleru Lake [8]

The total area under aquaculture in Andhra Pradesh is 1.96 lakh ha. (Includes Brackish Water area of 0.58 lakh ha and fresh water area of 1.38 lakh ha.). The Govt., of Andhra Pradesh has identified the fisheries as one of the growth engine under primary sector mission for achieving double digit inclusive growth. The A.P. Fisheries Policy, 2015 envisages to achieve the fish production from 27.66 lakh tonnes (2016-2017) to 42 lakh tonnes with a (Gross Value Added) GVA of Rs. 80,000 crore by 2019-20. [9]. West Godavari District is a hub of all aquaculture activities in Andhra Pradesh. The region contributes as much as $60 \%$ of the fish production from the State. The major aqua products in the region are fish and shrimp. The total fish production in the district was $10,51,754$ tons with GVA Rs 10088 crores for the year 2017-18. However there is a paradigm shift from capture to culture fisheries with the onset of several man made technologies. The aqua culture activity in the following 6 mandals of West Godavari District, AP, India are identified to have direct impact on the Kolleru Lake as these are located in the catchment and in close proximity to the Kolleru Lake [10].

Table - 1 Extent of Aqua culture in Kolleru Lake catchment mandals in West Godavari District, AP, India.

\begin{tabular}{|l|l|l|l|l|}
\hline $\begin{array}{l}\text { S1. } \\
\text { No }\end{array}$ & $\begin{array}{l}\text { Name of } \\
\text { the Mandal }\end{array}$ & $\begin{array}{l}\text { Saline } \\
\text { water aqua } \\
\text { culture } \\
\text { with } \\
\text { salinity } \\
>0.5 \mathrm{ppt} \\
\text { (acres) }\end{array}$ & $\begin{array}{l}\text { Fresh water } \\
\text { aqua culture } \\
\text { with salinity } \\
<0.5 \mathrm{ppt} \\
\text { (acres) }\end{array}$ & $\begin{array}{l}\text { Total } \\
\text { (acres) }\end{array}$ \\
\hline 1. & Bhimadole & 86.25 & 4131.35 & 4217.61 \\
\hline 2. & Nidamarru & 1415.73 & 4276.69 & 5692.42 \\
\hline 3. & Pedapadu & 0.00 & 4557.93 & 4557.926 \\
\hline 4. & Eluru & 321.00 & 5077.71 & 5398.71 \\
\hline 5. & Denduluru & 0.00 & $2246: 41$ & 2246.41 \\
\hline 6. & Unguturu & 0.00 & 2237.90 & 2237.9 \\
\hline & Total & 1822.98 & 20375.19 & 24350.98 \\
\hline
\end{tabular}

Source - Fisheries Department, West Godavari District.[10]

Availability of water with salinity $<0.5 \mathrm{ppt}$ is conducive only for fish culture than the shrimp culture hence fish culture is predominant in the above area. The wastewater discharges from the fish ponds in this area containing moderate pollution load reach Kolleru lake through inlet drains with in short time owing to close proximity to the lake and have direct impact on the lake water quality as there is no adequate time of travel for the stream/ drain for its self-purification.

Global interest in simple, safe, cost effective, sustainable green technologies has lead to the gradual development and refinement of Constructed Wetland $(\mathrm{CW})$ or artificial wetland systems for wastewater remediation $[11,12]$. Since the 1990s, domestic and industrial waste streams were treated using constructed wetland systems which includes runoff waters from agriculture, fish and animal farms, wastewaters from tannery, pulp and paper, textile industry, etc., [13 -17]. A study stated that the nutrient values are found in excess concentrations from sewage, industrial discharges, and agricultural runoff and aquaculture practices released into water bodies [18]. The intensive/semi intensive fish culture can release wastewater rich in nitrogen, phosphorus and Biochemical Oxygen Demand (BOD), suspended particles. In many developed countries conventional wastewater treatment technologies are implemented for the aquaculture wastewater treatment [19-20] but due to the high cost and huge power requirement of these technologies, many developing countries are focusing to construct low cost and less maintenance wastewater treatment technologies [21]. Thus, constructed wetlands (CWs) can be an economical and sustainable option for treatment of aquaculture wastewater in terms of low-cost, eco-friendly, and almost effective efficiency in wastewater treatment over the conventional treatment methods.

In view of this, the present study is carried out on the 
treatment of wastewater collected from fish ponds discharges which are released into Kolleru Lake through different drains deteriorating its water quality. By considering the treatment of wastewater joining into the lake water at the source i.e., a Baffle Wall Constructed Wetland (BWCW) using two different macrophytes, Eichhornia crassipes and emergent reed, namely, Typha angustata. These aquatic plants are native, grow in water as emergent, submerged and free floating and are used for treatment of waste water because of their more rapid biomass production, capability of higher uptake of elements for their growth $[22,23]$.

\section{MATERIALS AND MethodS}

\section{A. Study area and Site Selection Criteria}

Kolleru Lake basin is classified as semi-arid climate zone with normal annual rainfall being $715 \mathrm{~mm}$. The anthropogenic sources are deteriorating the quality of water in the lake area [24]. Among the major inlet drains Tammileru drain is the $2^{\text {nd }}$ highest contributor of water input into Kolleru Lake. Tammileru drain originates from Khammam District in Telangana State, India and upper stretches of West Godavari District, AP, India having a catchment area of 523 sq miles and with a peak discharge of 28,330 cusecs during flood. The drain bifurcates into East Tammileru and West Tammileru before Eluru City, traverses Eluru city and further flows downstream to join Kolleru Lake through Eluru Mandal. The Villages on the banks of Tammileru before confluence into Kolleru Lake in Eluru Mandal of West Godavari District were selected as the study area as there are many aquaculture ponds existing in this area and this area is in the immediate catchment of Kolleru Lake where aqua culture is predominant and is taken up in an extent of 5398.71 acres [10]. Due to availability of water with salinity $<0.5 \mathrm{ppt}$, fish culture is practiced in most of the aqua culture ponds in the area to culture two major species Labeo rohita and Catla catla along with Cirrhinus Mrigala. Sample collection was taken up in four seasons from the fish ponds discharging wastewater into the sub-drains of inlet drains of Kolleru Lake after the harvest of the fish in the study area.

\section{B. Method of sampling}

Usually the fish ponds, after 2 cycles of harvest, pump out the pond water. Most of the ponds discharge $20-25 \%$ of the pond water after the first harvest and refill the fresh water into the pond for taking up culture for the second season. All the ponds empty the entire pond after 2 or 3 harvests from the same pond and discharge into drains before starting the culture again. In the process of discharges, all the ponds use pumps to discharges pond water into the drain. The pond water being discharged into the drains was collected in four HDPE (High Density Poly Ethylene) drums of each 200 liters capacity each for the experiments in pilot plant i.e., Baffle Wall Constructed Wetland (BWCW). It was ensured that the time gap between the sample collection and the application in the BWCW is not exceeding 8-10 hours. However DO was fixed in situ for accuracy of analysis.

\section{Sampling frequency and analysis}

As per the designed plan of action, sampling for a period of fish pond discharge wastewaters were collected and an experimental study was carried out to reduce the concentrations of physico chemical parameters by treating in

one year covering all the four seasons was taken up. Samples were collected for six days in each season starting from December, 2018 in the following months in each season. Winter (December, 2018 to January, 2019), Summer (March, 2019 to April, 2019), Pre-monsoon (May, 2019 to June, 2019) and Post-Monsoon (October, 2019 to November, 2019). Water samples were collected, fixed up suitably (or preserved as desired) following standard procedures [25] and analyzed for $\mathrm{pH}$, EC BOD, COD, TDS, TSS, Nitrates and Phosphates in $\mathrm{M} / \mathrm{s}$. SV Enviro Labs, Visakhapatnam which is a NABL accredited laboratory on subsequent return from the field.

\section{Baffle Wall Constructed Wetland (BWCW)}

A free water surface flow type Baffle Wall Constructed Wetland (BWCW) was fabricated for treating the discharges collected from fish ponds. The BWCW was divided into two different units. Both the Units are packed with native benthic soil brought from the drain and then planted with two categories of macrophytes, viz., floating weed, namely, Echhornia crassipes in Unit I and emergent reed, namely, Typha angustata in Unit II which are native to the drain. The constructed wet land is designed with Baffle Walls to overcome the deficiencies identified in the earlier studies like short circuiting, creation of anaerobic zones and Mosquito menace. The constructed wetland was designed for a Hydraulic Retention Time (HRT) 18 hours based on optimum treatment arrived by trail and error method and to enhance the efficiency of sedimentation six vertical baffle walls were provided in each Unit of BWCW as shown in Fig 3.

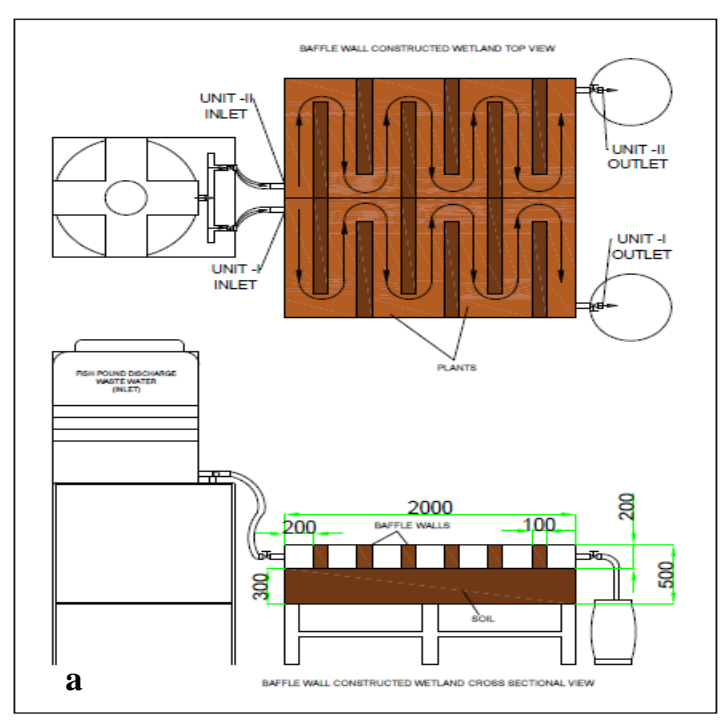




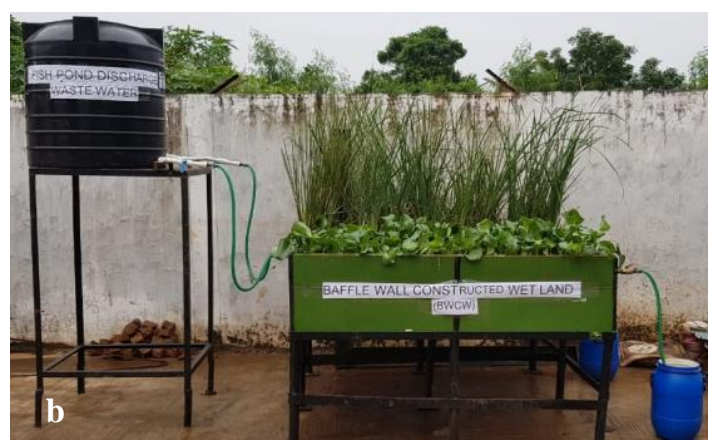

Fig 3. Baffle Wall Constructed Wet Land (BWCW) (a. Top view and $\mathrm{C} / \mathrm{S}$ view, b. working model)

Wastewater from the fish ponds is taken into the storage tank and feeding to the BWCW was controlled through valves to maintain 18 hours HRT. The bed was initially saturated with drain water and then the flow rate was regulated to attain a constant water column over the bed and flow between baffle walls leaving air layer (free board) above it within the cell. The BWCW is open to sky directly receiving sunlight, wind and slight precipitation. The experiment was carried out in four different seasons of a year i.e., winter, summer pre-monsoon and post-monsoon. The untreated water samples from the inlet and treated samples from the outlet of BWCW were collected respectively for 45 days intermittently at regular intervals in four different seasons of the year and analyzed for the physico chemical parameters i.e., pH, Electrical Conductivity (EC), Total Dissolved Solids (TDS), Total Suspended Solids (TSS), Bio-chemical Oxygen Demand (BOD), Chemical Oxygen Demand (COD), Nitrates and Phosphates which were identified for the current study.

\section{RESULTS AND STATISTICAL ANALYSIS}

The data analysis of the concentrations of the considered parameters in the fish pond discharge wastewater which is used as inlet for both the units of the free flow Baffle Wall constructed wetland i.e., the unit-I with (Eichhornia crasspics) and unit II with (Typha angustata) is presented in Table 2.

Table 2: Wastewater samples collected from fish pond discharges (Inlets of Unit I and II of BWCW) during different seasons.

\begin{tabular}{|c|c|c|c|c|}
\hline Parameters & Winter & Summer & Pre monsoon & Post monsoon \\
\hline $\mathrm{pH}$ & $\begin{array}{c}8.24 \pm 0.37 * \\
(8.66-7.72) * *\end{array}$ & $\begin{array}{c}8.31 \pm 0.18 \\
(8.56-8.06)\end{array}$ & $\begin{array}{c}7.67 \pm 0.10 \\
(7.82-7.56)\end{array}$ & $\begin{array}{c}7.99 \pm 0.54 \\
(8.66-7.38)\end{array}$ \\
\hline $\mathrm{EC}$ & $\begin{array}{c}2991.67 \pm 348.33 \\
(3808.52-2518.24)\end{array}$ & $\begin{array}{c}3120.16 \pm 580.17 \\
(3898.46-2132.38)\end{array}$ & $\begin{array}{c}3325.19 \pm 427.78 \\
(3804.68-2662.45)\end{array}$ & $\begin{array}{c}3091.97 \pm 729.34 \\
(4028.58-2239.42)\end{array}$ \\
\hline TDS & $\begin{array}{c}1935.40 \pm 399.25 \\
(2525.12-1510.96)\end{array}$ & $\begin{array}{c}2070.23 \pm 393.88 \\
(2863.44-1582.48)\end{array}$ & $\begin{array}{c}2154.51 \pm 354.39 \\
(2606.86-1650.72)\end{array}$ & $\begin{array}{c}1991.95 \pm 381.39 \\
(2684.34-1574.44)\end{array}$ \\
\hline TSS & $\begin{array}{c}88.42 \pm 26.67 \\
(126.36-52.32)\end{array}$ & $\begin{array}{c}63.02 \pm 38.39 \\
(118.72-32.42)\end{array}$ & $\begin{array}{c}77.85 \pm 28.40 \\
(118.88-48.14)\end{array}$ & $\begin{array}{c}52.70 \pm 7.75 \\
(64.48-42.04)\end{array}$ \\
\hline BOD & $\begin{array}{c}27.51 \pm 8.68 \\
(38.86-12.68)\end{array}$ & $\begin{array}{c}23.68 \pm 9.56 \\
(40.24-12.32)\end{array}$ & $\begin{array}{c}25.90 \pm 11.87 \\
(44.88-9.02)\end{array}$ & $\begin{array}{c}18.93 \pm 8.25 \\
(28.72-8.28)\end{array}$ \\
\hline COD & $\begin{array}{c}80.52 \pm 28.55 \\
(120.92-50.16) \\
\end{array}$ & $\begin{array}{c}71.83 \pm 23.99 \\
(144.94-45.36)\end{array}$ & $\begin{array}{c}75.97 \pm 26.68 \\
(108.22-32.12) \\
\end{array}$ & $\begin{array}{c}63.33 \pm 17.51 \\
(88.38-40.42) \\
\end{array}$ \\
\hline Nitrates & $\begin{array}{c}2.94 \pm 1.33 \\
(4.68-1.42)\end{array}$ & $\begin{array}{c}4.03 \pm 2.05 \\
(6.78-2.24)\end{array}$ & $\begin{array}{c}3.63 \pm 1.73 \\
(5.28-1.34)\end{array}$ & $\begin{array}{c}2.74 \pm 0.66 \\
(3.68-1.86)\end{array}$ \\
\hline Phosphates & $\begin{array}{c}1.86 \pm 0.67 \\
(2.84-1.04) \\
\end{array}$ & $\begin{array}{c}2.27 \pm 0.81 \\
(3.26-1.36) \\
\end{array}$ & $\begin{array}{c}1.68 \pm 0.71 \\
(2.66-0.94)\end{array}$ & $\begin{array}{c}1.90 \pm 0.92 \\
(3.08-0.84) \\
\end{array}$ \\
\hline \multicolumn{5}{|c|}{$\begin{array}{l}\text { * Values in the table are corresponding to mean values; } \pm \text {, standard deviations } \\
\text { ** Values given in the parenthesis are maximum and minimum values of respective parameters. } \\
\text { pH - Potentio hydrogen, EC - Electrical conductivity }(\mu \mathrm{mho} / \mathrm{cm}) \text {, TDS - Total dissolved solids (mg/l), TSS - Total } \\
\text { suspended solids (mg/1), BOD - Biochemical Oxygen Demand (mg/l), COD - Chemical Oxygen Demand (mg/l), } \\
\mathrm{NO}_{3}^{-}-\text {Nitrates (mg/l), } \mathrm{PO}_{4}^{-3} \text { - Phosphates }(\mathrm{mg} / \mathrm{l}) \text {. }\end{array}$} \\
\hline
\end{tabular}

The concentrations of the analyzed parameters in the inlet of BWCW are ranging from $\mathrm{pH}$ 8.6-7.38, Electrical conductivity (EC) $4028.58-2132.38 \mu \mathrm{mho} / \mathrm{cm}$, Total Dissolved Solids (TDS) 2863.44-1510.96 mg/l, Total Suspended Solids (TSS) 126.36-32.42 mg/l, BOD 44.88-8.28 $\mathrm{mg} / \mathrm{l}, \mathrm{COD}, 144.94-32.12 \mathrm{mg} / \mathrm{l}$, Nitrates 6.78-1.34 mg/l, Phosphates 3.26-0.84 mg/l.

The value of $\mathrm{pH}$ of the sample is within the limit prescribed in inland surface water quality discharge standards (5.5-9.0). EC was observed to be high in all the seasons as reported similarly [26] which indicates higher availability of nutrients in the effluents due to which EC also increases. The TDS concentrations are above the limit prescribed in the inland surface water quality discharge standards $(2100 \mathrm{mg} / \mathrm{l})$ in most of the samples. TSS values are also above the limits prescribed for Inland surface water quality discharge standards (100 mg/l) [27] evaluated in his research that suspension of solids present in the discharges from bottom of a fish pond increases the concentration of BOD, COD and TSS. Though BOD levels are within the limits prescribed for Inland surface water quality discharge standards $(30 \mathrm{mg} / \mathrm{l})$ in most of the samples, however the BOD levels in the 
discharges would increase the BOD level in the receiving drain which might exceed the prescribed limit of $3 \mathrm{mg} / \mathrm{l}$ as per the stream/river water quality criteria prescribed by CPCB. High value of BOD in all the samples could be attributed to the presence of organic matter in the aqua culture discharges. Similar results were observed by [28]. A studyobserved higher values of BOD during monsoon due to input of organic wastes and enhanced bacterial activity in certain freshwater ecosystem of Santal Pargana, (Jharkhand) [29]. Comparing the concentrations of COD in the samples in the different seasons, maximum concentrations are observed during winter and minimum during post-monsoon season. The nitrates concentration are within the limit of $10.0 \mathrm{mg} / \mathrm{l}$ which is permissible limits of inland surface water quality discharge standards and the concentrations of phosphates also within limit prescribed. But a research found that presence of nitrates in the fish pond water is related to the nitrification and denitrification processes [27]. The increase in concentration of nutrients in the water because of fish excretion and feed leftovers in huge volumes found due to high cultivation densities and daily use of rations in the same fish pond [30]. In previous studies it was also observed that the phosphates concentrations ranged from 0.01 to $0.07 \mathrm{mg} / \mathrm{l}$ in medium size fish ponds [27]. In one context of their study found that the water volume is not much big and the amount of organic matter present in the sediment causes great changes in the nitrates and phosphates concentrations. Even this small

Table 3: Treated fish ponds water samples collected at outlet of Unit 1 (Eichhornia crasspics) in BWCW during different seasons

\begin{tabular}{|c|c|c|c|c|}
\hline Parameters & Winter & Summer & Pre monsoon & Post monsoon \\
\hline $\mathrm{pH}$ & $\begin{array}{c}7.81 \pm 0.33 * \\
(8.22-7.37) * * \\
\end{array}$ & $\begin{array}{c}7.36 \pm 0.16 \\
(7.48-7.07) \\
\end{array}$ & $\begin{array}{c}7.21 \pm 0.05 \\
(7.21-6.86) \\
\end{array}$ & $\begin{array}{c}7.65 \pm 0.32 \\
(8.01-7.26) \\
\end{array}$ \\
\hline $\mathrm{EC}$ & $\begin{array}{c}1983.02 \pm 222.72 \\
(2543.33-1722.98)\end{array}$ & $\begin{array}{c}1845.82 \pm 318.91 \\
(2180.80-1223.56)\end{array}$ & $\begin{array}{c}2038.80 \pm 309.69 \\
(2345.97-1526.12)\end{array}$ & $\begin{array}{c}1964.77 \pm 397.95 \\
(2421.98-1477.12)\end{array}$ \\
\hline TDS & $\begin{array}{c}1238.31 \pm 249.40 \\
(1632.74-989.07)\end{array}$ & $\begin{array}{c}1182.34 \pm 202.91 \\
(1543.97-872.58)\end{array}$ & $\begin{array}{c}1286.85 \pm 235.84 \\
(1555.25-925.72)\end{array}$ & $\begin{array}{c}1236.00 \pm 194.75 \\
(1580.54-1017.72)\end{array}$ \\
\hline TSS & $\begin{array}{c}42.27 \pm 12.19 \\
(60.80-26.25)\end{array}$ & $\begin{array}{c}24.32 \pm 13.69 \\
(41.94-12.20)\end{array}$ & $\begin{array}{c}35.01 \pm 13.22 \\
(53.54-19.80)\end{array}$ & $\begin{array}{c}24.61 \pm 2.57 \\
(27.93-20.50)\end{array}$ \\
\hline BOD & $\begin{array}{c}11.20 \pm 3.49 \\
(16.54-5.61) \\
\end{array}$ & $\begin{array}{c}7.83 \pm 2.97 \\
(12.44-3.93) \\
\end{array}$ & $\begin{array}{c}9.69 \pm 4.63 \\
(16.87-3.00) \\
\end{array}$ & $\begin{array}{c}7.30 \pm 2.95 \\
(10.18-3.41) \\
\end{array}$ \\
\hline COD & $\begin{array}{c}36.82 \pm 12.70 \\
(56.45-24.16) \\
\end{array}$ & $\begin{array}{c}26.66 \pm 8.13 \\
(49.16-15.94) \\
\end{array}$ & $\begin{array}{c}30.92 \pm 11.59 \\
(44.02-11.64) \\
\end{array}$ & $\begin{array}{c}26.58 \pm 6.18 \\
(33.97-18.09) \\
\end{array}$ \\
\hline Nitrates & $\begin{array}{c}1.52 \pm 0.68 \\
(2.46-0.76) \\
\end{array}$ & $\begin{array}{c}1.80 \pm 0.86 \\
(2.94-0.98) \\
\end{array}$ & $\begin{array}{c}1.74 \pm 0.85 \\
(2.54-0.59) \\
\end{array}$ & $\begin{array}{c}1.36 \pm 0.28 \\
(1.70-0.93) \\
\end{array}$ \\
\hline Phosphates & $\begin{array}{c}1.00 \pm 0.35 \\
(1.55-0.59)\end{array}$ & $\begin{array}{c}1.02 \pm 0.34 \\
(1.40-0.59)\end{array}$ & $\begin{array}{c}0.80 \pm 0.36 \\
(1.27-0.41)\end{array}$ & $\begin{array}{c}0.94 \pm 0.45 \\
(1.47-0.44)\end{array}$ \\
\hline \multicolumn{5}{|c|}{$\begin{array}{l}\text { * Values in the table are corresponding to mean values; } \pm \text { standard deviations } \\
\text { ** Values given in the parenthesis are maximum and minimum values of respective parameters. } \\
\text { pH - Potential of hydrogen, EC - Electrical conductivity }(\mu \mathrm{mho} / \mathrm{cm}), \text { TDS - Total dissolved solids }(\mathrm{mg} / \mathrm{l}) \text {, TSS - } \\
\text { Total suspended solids }(\mathrm{mg} / \mathrm{l}), \mathrm{BOD}-\text { Biochemical Oxygen Demand }(\mathrm{mg} / \mathrm{l}), \mathrm{COD}-\mathrm{Chemical} \text { Oxygen Demand } \\
(\mathrm{mg} / \mathrm{l}), \mathrm{NO}_{3}^{-}-\text {Nitrates }(\mathrm{mg} / \mathrm{l}), \mathrm{PO}_{4}^{-3}-\text { Phosphates }(\mathrm{mg} / \mathrm{l}) \text {. }\end{array}$} \\
\hline
\end{tabular}

concentrations of phosphates mixes with other agricultural wastes may affect the fresh water bodies by contributing to eutrophication activities enriching phosphate in the lake [31].

Studies stating that aquaculture wastewater is highly rich in suspended solids, nutrients are having such an adverse effects on the environment that they cannot release directly into fresh water bodies without treatment [32-34]. By evaluating various parameters in the above fish pond wastewater discharge samples it is observed that the parameters TDS and BOD are exceeding the permissible limits of inland surface water quality standards. Hence require treatment for reduction of concentration of various parameters to maintain the receiving water bodies within the limits of River water quality criteria prescribed by CPCB.

The data analysis of the concentrations of the considered parameters after treatment in both the units of the free flow Baffle Wall constructed wetland i.e., the Unit I with (Eichhornia crasspics) and Unit II with (Typha angustata) are presented in Table 3 and Table 4 respectively.

The concentration of the analyzed parameters in the outlet of Unit 1 (Eichhornia crasspics) BWCW are ranging from pH 8.22-6.86, Electrical conductivity (EC) 2543.33-1223.56 $\mu \mathrm{mho} / \mathrm{cm}$, Total Dissolved Solids (TDS) 1632.74-872.58 $\mathrm{mg} / \mathrm{l}$, Total Suspended Solids (TSS) 60.80-12.20 mg/l, BOD 16.87-3.00 mg/l, COD 56.45-11.64 mg/l, Nitrates 2.94-0.59 $\mathrm{mg} / \mathrm{l}$, Phosphates $1.55-0.41 \mathrm{mg} / \mathrm{l}$. 
Assessment of Free Flow Baffle Wall Constructed Wetland (BWCW) for treating wastewater discharges from fish culture ponds in Kolleru area

Table 4 Treated fish ponds water samples collected at outlet of Unit 2 (Typha angustata) in BWCW during different seasons

\begin{tabular}{|c|c|c|c|c|}
\hline Parameters & Winter & Summer & Pre monsoon & Post monsoon \\
\hline $\mathrm{pH}$ & $\begin{array}{c}7.95 \pm 0.31 * \\
(8.43-7.58) * *\end{array}$ & $\begin{array}{c}7.66 \pm 0.14 \\
(7.78-7.42) \\
\end{array}$ & $\begin{array}{c}7.33 \pm 0.14 \\
(7.52-7.15) \\
\end{array}$ & $\begin{array}{c}7.71 \pm 0.48 \\
(8.29-7.15) \\
\end{array}$ \\
\hline $\mathrm{EC}$ & $\begin{array}{c}1883.18 \pm 204.22 \\
(2424.50-1656.50)\end{array}$ & $\begin{array}{c}1796.77 \pm 311.94 \\
(2095.81-1186.46)\end{array}$ & $\begin{array}{c}1977.52 \pm 284.34 \\
(2333.03-1543.69)\end{array}$ & $\begin{array}{c}1919.49 \pm 458.59 \\
(2440.51-1337.82)\end{array}$ \\
\hline TDS & $\begin{array}{c}1182.21 \pm 237.30 \\
(1557.49-958.86)\end{array}$ & $\begin{array}{c}1146.69 \pm 191.25 \\
(1483.26-853.27)\end{array}$ & $\begin{array}{c}1250.75 \pm 231.51 \\
(1510.42-900.63)\end{array}$ & $\begin{array}{c}1198.53 \pm 188.96 \\
(1534.37-988.12)\end{array}$ \\
\hline TSS & $\begin{array}{c}44.01 \pm 12.63 \\
(63.58-27.61)\end{array}$ & $\begin{array}{c}27.04 \pm 15.46 \\
(47.44-13.55)\end{array}$ & $\begin{array}{c}36.32 \pm 13.51 \\
(55.23-20.59)\end{array}$ & $\begin{array}{c}25.53 \pm 2.67 \\
(29.00-21.43)\end{array}$ \\
\hline BOD & $\begin{array}{c}11.77 \pm 3.57 \\
(16.97-5.80) \\
\end{array}$ & $\begin{array}{c}8.60 \pm 3.28 \\
(13.36-4.21) \\
\end{array}$ & $\begin{array}{c}10.25 \pm 4.70 \\
(17.40-3.16) \\
\end{array}$ & $\begin{array}{c}7.98 \pm 3.48 \\
(11.65-3.19) \\
\end{array}$ \\
\hline COD & $\begin{array}{c}37.62 \pm 12.71 \\
(57.00-24.85)\end{array}$ & $\begin{array}{c}28.34 \pm 8.58 \\
(51.89-17.20)\end{array}$ & $\begin{array}{c}33.06 \pm 12.25 \\
(47.21-12.67)\end{array}$ & $\begin{array}{c}28.07 \pm 7.67 \\
(37.58-16.52)\end{array}$ \\
\hline Nitrates & $\begin{array}{c}1.37 \pm 0.60 \\
(2.21-0.69)\end{array}$ & $\begin{array}{c}1.65 \pm 0.78 \\
(2.72-0.89)\end{array}$ & $\begin{array}{c}1.61 \pm 0.79 \\
(2.35-0.54)\end{array}$ & $\begin{array}{c}1.21 \pm 0.29 \\
(1.57-0.86)\end{array}$ \\
\hline Phosphates & $\begin{array}{c}0.91 \pm 0.32 \\
(1.40-0.54)\end{array}$ & $\begin{array}{c}0.98 \pm 0.33 \\
(1.35-0.57)\end{array}$ & $\begin{array}{c}0.78 \pm 0.35 \\
(1.24-0.40)\end{array}$ & $\begin{array}{c}0.89 \pm 0.44 \\
(1.40-0.41)\end{array}$ \\
\hline \multicolumn{5}{|c|}{$\begin{array}{l}\text { * Values in the table are corresponding to mean values; } \pm \text {, standard deviations } \\
\text { ** Values given in the parenthesis are maximum and minimum values of respective parameters. } \\
\text { pH - Potential of hydrogen, EC - Electrical conductivity ( } \mu \text { mho/cm), TDS - Total dissolved solids (mg/l), } \\
\text { TSS - Total suspended solids (mg/l), BOD - Biochemical Oxygen Demand (mg/l), COD - Chemical Oxygen } \\
\text { Demand (mg/l), } \mathrm{NO}_{3}-\text { - Nitrates (mg/l), } \mathrm{PO}_{4}^{-3}-\text { Phosphates }(\mathrm{mg} / 1) \text {. }\end{array}$} \\
\hline
\end{tabular}

The concentration of the analyzed parameters in the outlet of Unit II (Typha angustata) of the BWCW are ranging from $\mathrm{pH}$ 8.43-7.15, Electrical conductivity (EC) 2440.51-1186.46 $\mu \mathrm{mho} / \mathrm{cm}^{2}$, Total Dissolved Solids (TDS) 1557.49-853.27 $\mathrm{mg} / \mathrm{l}$, Total Suspended Solids (TSS) 63.58-13.55 mg/l, BOD 17.4-3.16 mg/l, COD 57.00-12.67 mg/l, Nitrates 2.72-0.54 $\mathrm{mg} / \mathrm{l}$, Phosphates 1.40-0.40 mg/l.

The concentrations in the treated wastewater in outlet samples of Unit I and Unit II of BWCW are observed that $\mathrm{pH}$ is almost nearly 7.5 or neutral. Similar results were observed by [35-37] and it was also discussed that rise of $\mathrm{pH}$ to neutral condition is basically attributed to the biochemical processes. Plants can absorb anions such as nitrates and phosphates for their growth and, eventually, the reduction of acid forming anions increase the $\mathrm{pH}$ in wastewater. Similarly, Electrical Conductivity, TDS, TSS, BOD, COD, Nitrates and Phosphates concentration is observed to be reduced in all outlet samples of wastewater than the inlet samples in all the Units and seasons.

Similar results are reported by some of earlier studies [38] stated that in the study of constructed wetland with macrophytes, the EC may reduce due to utilization of soluble degraded product by the macrophytes. Suspended matter is removed primarily through the mechanism of interception, sedimentation, aggregation and settling [39]. Floating plants such Eichhornia crassipes lower the water velocities and increase the adsorption by biofilms over their root systems to further enhance the above processes very effectively [38, 40-42]. The organic load in constructed wetlands is assumed to be removed by the inclusive actions of microorganisms present in the underneath aerobic and anaerobic pockets, plants roots, rhizomes and cell bed, hence the reduction in BOD takes place [43-45]. COD removal processes in constructed wetlands was reported to be by volatization, photochemical ordination, sedimentation, sorption and biodegradation [46], also it was recognized that floating plants in constructed wetlands improve removal rates of COD and TSS to a considerable extent [47]. Constructed wetlands attributed higher nutrient removal simultaneous nitrification and denitrification processes [48]. Phosphate removal in constructed wetlands is mainly due to its adsorption by soil as the same is capable of adsorbing both cations and anions [49]. In slow flowing waters, while particulate phosphate settles and remains in bed material, soluble phosphorous is taken up onto media, biofilms and detritus through precipitation, complexation and assimilation by microbial and plant biomass [50].

\section{REMOVAL EFFICIENCY OF BWCW}

The removal efficiency of the considered parameters treated in BWCW was calculated using the following method.

Physico-chemical removal efficiency of BWCW in the case of each monitored variable was calculated from their quantitative difference in water at the inlet and outlet and expressed as

Elemental removal efficiency in $\%$ by the BWCW

$=[($ Ei-Eo $) /$ Ei $] \times 100$

$\mathrm{Ei}=$ Element concentration in inlet water

Eo= Element concentration in outlet water

The data analysis of the removal efficiency of the considered parameters after treatment in both the units of the free flow Baffle Wall Constructed Wetland i.e., the Unit I with (Eichhornia crasspics) and Unit II with (Typha angustata) are presented in Table 5 and Table 6 respectively. 
Table 5 Efficiency (\%) of BWCW in treating fish pond water samples at Unit 1 (Eichhornia crasspics) in BWCW during different seasons

\begin{tabular}{|c|c|c|c|c|}
\hline Seasons & Winter & Summer & Pre-monsoon & Post monsoon \\
\hline $\mathrm{pH}$ & $\begin{array}{c}5.27 \pm 0.88^{*} \\
(6.31-4.02)^{* *}\end{array}$ & $\begin{array}{c}11.38 \pm 1.13 \\
(12.66-9.84)\end{array}$ & $\begin{array}{c}5.95 \pm 1.39 \\
(7.67-4.23)\end{array}$ & $\begin{array}{c}4.12 \pm 2.85 \\
(7.51-0.80) \\
\end{array}$ \\
\hline $\mathrm{EC}$ & $\begin{array}{c}33.64 \pm 2.62 \\
(37.56-30.26)\end{array}$ & $\begin{array}{c}40.73 \pm 2.21 \\
(44.06-38.34)\end{array}$ & $\begin{array}{c}38.85 \pm 2.30 \\
(42.68-36.72)\end{array}$ & $\begin{array}{c}36.05 \pm 2.30 \\
(39.88-33.92)\end{array}$ \\
\hline TDS & $\begin{array}{c}35.93 \pm 1.89 \\
(38.84-33.86)\end{array}$ & $\begin{array}{c}42.73 \pm 2.38 \\
(46.08-40.02)\end{array}$ & $\begin{array}{c}40.43 \pm 2.27 \\
(43.92-37.94)\end{array}$ & $\begin{array}{c}37.63 \pm 2.27 \\
(41.12-35.14)\end{array}$ \\
\hline TSS & $\begin{array}{c}51.93 \pm 2.25 \\
(55.44-49.40) \\
\end{array}$ & $\begin{array}{c}60.64 \pm 2.64 \\
(64.84-57.84) \\
\end{array}$ & $\begin{array}{c}55.25 \pm 2.29 \\
(58.88-52.66) \\
\end{array}$ & $\begin{array}{c}53.05 \pm 2.29 \\
(56.68-50.46) \\
\end{array}$ \\
\hline BOD & $\begin{array}{c}57.93 \pm 2.36 \\
(61.52-55.58) \\
\end{array}$ & $\begin{array}{c}66.70 \pm 2.17 \\
(70.22-64.36) \\
\end{array}$ & $\begin{array}{c}63.06 \pm 2.25 \\
(66.76-61.04) \\
\end{array}$ & $\begin{array}{c}60.86 \pm 2.25 \\
(64.56-58.84) \\
\end{array}$ \\
\hline COD & $\begin{array}{c}54.00 \pm 2.40 \\
(57.88-51.42)\end{array}$ & $\begin{array}{c}62.64 \pm 2.38 \\
(66.08-60.22) \\
\end{array}$ & $\begin{array}{c}59.78 \pm 2.50 \\
(63.76-57.28)\end{array}$ & $\begin{array}{c}57.58 \pm 2.50 \\
(61.56-55.08)\end{array}$ \\
\hline Nitrates & $\begin{array}{c}47.94 \pm 2.44 \\
(52.04-45.28)\end{array}$ & $\begin{array}{c}54.84 \pm 2.08 \\
(58.06-52.64)\end{array}$ & $\begin{array}{c}52.43 \pm 2.45 \\
(55.94-49.84)\end{array}$ & $\begin{array}{c}50.23 \pm 2.45 \\
(53.74-47.64)\end{array}$ \\
\hline Phosphates & $\begin{array}{c}45.78 \pm 2.33 \\
(49.44-43.04)\end{array}$ & $\begin{array}{c}54.58 \pm 2.69 \\
(58.84-52.08)\end{array}$ & $\begin{array}{c}52.74 \pm 2.60 \\
(56.84-50.12)\end{array}$ & $\begin{array}{c}50.69 \pm 2.42 \\
(54.64-48.08)\end{array}$ \\
\hline
\end{tabular}

It is established from the above results that treatment of fish pond discharge wastewater in the unit-I (Eichhornia crasspics) of the free flow Baffle Wall constructed wetland could achieve the reduction efficiencies ranging from $30.26 \%$ - $44.06 \%$ for Electrical conductivity (EC), 33.86\% - 46.08\% for Total Dissolved Solids (TDS), $49.40 \%-64.84 \%$ for Total
Suspended Solids (TSS), 55.58\% - 70.22\% for BOD, $51.42 \%$ $-66.08 \%$ for COD , $45.28 \%-58.06 \%$ for Nitrates, $43.04 \%$ $58.84 \%$ for Phosphates in reduction of the inlet concentration to treated water concentrations in. The removal efficiency was highest in summer and least in winter season.

Table 6 Efficiency (\%) of BWCW in treating fish pond water samples at Unit 2 (Typha angustata) in BWCW during different seasons.

\begin{tabular}{|c|c|c|c|c|}
\hline Seasons & Winter & Summer & Pre-monsoon & Post monsoon \\
\hline \multirow{2}{*}{$\mathrm{pH}$} & $\begin{array}{c}3.51 \pm 2.02^{*} \\
(5.70-0.54)^{* *}\end{array}$ & $\begin{array}{c}7.76 \pm 0.77 \\
(9.18-7.08)\end{array}$ & $\begin{array}{c}4.33 \pm 1.41 \\
(6.56-2.84)\end{array}$ & $\begin{array}{c}3.45 \pm 1.01 \\
(4.39-2.02)\end{array}$ \\
\hline \multirow{2}{*}{ EC } & $36.95 \pm 2.42$ & $42.30 \pm 2.50$ & $40.47 \pm 4.66$ & $37.87 \pm 4.66$ \\
& $(40.68-34.22)$ & $(46.24-40.20)$ & $(48.88-36.42)$ & $(46.28-33.82)$ \\
\hline \multirow{2}{*}{ TDS } & $38.80 \pm 2.45$ & $44.42 \pm 2.44$ & $42.12 \pm 1.99$ & $39.52 \pm 1.99$ \\
& $(42.84-36.34)$ & $(48.20-42.02)$ & $(45.44-39.84)$ & $(42.84-37.24)$ \\
\hline \multirow{2}{*}{ TSS } & $49.91 \pm 2.53$ & $56.43 \pm 2.25$ & $53.50 \pm 2.42$ & $51.30 \pm 2.42$ \\
& $(53.76-47.22)$ & $(60.04-54.36)$ & $(57.22-50.66)$ & $(55.02-48.46)$ \\
\hline \multirow{2}{*}{ BOD } & $56.88 \pm 2.51$ & $63.54 \pm 2.54$ & $60.71 \pm 2.38$ & $58.00 \pm 2.17$ \\
& $(61.06-54.2)$ & $(67.24-61.36)$ & $(64.98-58.62)$ & $(61.44-55.84)$ \\
\hline \multirow{2}{*}{ COD } & $52.92 \pm 2.32$ & $60.25 \pm 2.46$ & $56.90 \pm 2.31$ & $55.71 \pm 2.28$ \\
& $(56.62-50.4)$ & $(64.20-58.24)$ & $(60.54-54.38)$ & $(59.14-53.20)$ \\
\hline \multirow{2}{*}{ Nitrates } & $53.12 \pm 2.18$ & $58.43 \pm 2.59$ & $56.10 \pm 2.25$ & $55.95 \pm 2.15$ \\
& $(56.32-50.6)$ & $(62.64-56.14)$ & $(59.78-53.74)$ & $(59.36-53.82)$ \\
\hline \multirow{2}{*}{ Phosphates } & $50.86 \pm 2.56$ & $56.53 \pm 2.3$ & $53.74 \pm 2.60$ & $53.49 \pm 2.51$ \\
& $(55.04-48.3)$ & $(60.38-54.64)$ & $(57.84-51.12)$ & $(57.48-50.44)$ \\
\hline \multirow{2}{*}{$*$ Values in the table are corresponding to mean values; \pm standard deviations } & \\
$*$ * Values given in the parenthesis are maximum and minimum values of respective parameters.
\end{tabular}

The unit II (Typha angustata) of the free flow Baffle Wall constructed wetland could achieve the reduction efficiencies ranging from $33.82 \%-48.88 \%$ for Electrical conductivity (EC), 36.34\% - 48.20\% for Total Dissolved Solids (TDS), $47.22 \%-60.04 \%$ for Total Suspended Solids (TSS), $54.24 \%$ - $67.24 \%$ for BOD, $50.46 \%-64.2 \%$ for COD, $50.62 \%$ -
$62.64 \%$ for Nitrates, $48.32 \%-60.38 \%$ for Phosphates in reduction of the inlet concentration to treated water concentrations. The removal efficiency was highest in summer and least in winter season.

The removal efficiency in unit II with (Typha angustata) is observed to be better for the parameters EC, TDS, Nitrates and Phosphates. However the removal efficiency in Unit I 


\section{Assessment of Free Flow Baffle Wall Constructed Wetland (BWCW) for treating wastewater discharges from fish culture ponds in Kolleru area}

with (Eichhornia crasspics) is observed to be better for the parameters TSS, BOD and COD.

The present study from BWCW revealed that pollutant removal efficiencies of the parameters $\mathrm{pH}$, Nitrates and Phosphates are comparable and similar with the study results of [51]. TSS reductions is to a great extent related to higher bacterial diversity and density in cells with $50 \%$ [52]. The studies [39] on free surface flow constructed wetlands concluded that $>70 \%$ removal efficiencies for TSS, COD and BOD achieved. A positive correlation was noticed between wastewater retention time and removal rates between the results from the current BWCW study and the study carried out by [53, 54]. Eichhornia crassipes has a high removal efficiency for the physico chemical parameters as also observed by during their batch experiments using laboratory-scale non-aerated hydroponic bio-filtration system [55]. The current study established higher removal efficiencies for the parameters TDS, TSS, BOD, COD, Nitrates and Phosphates during summer followed by Pre-monsoon, Post-monsoon and Winter season which may be due to the increase in the bacterial growth, decomposition activities with increase in temperatures which was also established similarly by [56].

\section{CONCLUSION}

The study established that fish pond wastewater discharges can be effectively treated using Free Flow Baffle Wall Constructed Wetland which does not require skilled labor, high power requirement, and it is Eco-friendly and a sustainable green technology. The establishment cost and operational and maintenance costs are very low making it a cost effective treatment option and can reduce the pollution load entering the Kolleru Lake by around $50 \%$.

\section{ACKNOWLEDGMENT}

The authors acknowledge M/s. SV Enviro Labs \& Consultants, Visakhapatnam for the analytical and infrastructure support. We thank the officers of AP Pollution Control Board, Regional office, Eluru, Officials of Fisheries Department, Eluru, Owners of Fish ponds in Eluru Mandal, West Godavari District and other colleagues of AP Pollution Control Board Visakhapatnam and Vijayawada for their support and encouragement.

\section{REFERENCES}

[1] Brix, H., Schierup, HH. The use of aquatic macrophytes in waterpollution control.Ambio. 1989, 18, pp:100-107.

[2] Mishra, VK.,Upadhyay, AR., Pandey, SK.. Heavy metal pollution induced due to coal mining effluent on surrounding aquatic ecosystem and its management through naturally occurring aquatic macrophytes. 2008, Bioresour Technol., 99,pp: 930-936.

[3] Yang, H., Rose, NL., Trace element pollution records in some UK lake sediment, their history, influence factor and regional differences. 2005, Environmental Science and Technology, 31, pp: 63-75.

[4] Panigrahy, Sushma, T. V. R. Murthy, J. G. Patel, and T. S. Singh Wetlands of India: inventory and assessment at 1: 50,000 scale using geospatial techniques. 2012, Current science, pp: 852-856.

[5] Azeez, P. A., S. Ashok Kumar, B. C. Choudhury, V. N. V. K. Sastry, Sanjay Upadhyay, K. Mruthyunjaya Reddy, and K. KameshwaraRao. Report on the proposal for downsizing the Kolleru Wildlife Sanctuary (+ 5 to+ 3 feet contour). 2011, Ministry of Environment and Forests Government of India
[6] Jayanthi, Marappan, Peter NilaRekha, NatarajanKavitha, and PitchaiyappanRavichandran. Assessment of impact of aquaculture on Kolleru Lake (India) using remote sensing and Geographical Information System. Aquaculture research, 2006, 37, no. 16, pp: 1617-1626.

[7] Rao, K.N.; Krishna, G.M.; Malini, B. Kolleru lake is vanishing-A revelation through digital image processing of IRS-1D LISS III sensor data. Curr. Sci. 2004, 86, pp:1312-1316.

[8] Kolli, MeenaKumari, Christian Opp, Daniel Karthe, and Michael Groll. Mapping of Major Land-Use Changes in the Kolleru Lake Freshwater Ecosystem by Using Landsat Satellite Images in Google Earth Engine. 2020, Water 12, no. 9, pp: 2493.

[9] GO MS No. 16, AHDD\&F (Fish) Department, Govt. Andhra Pradesh, India. Dated 20.04.2018.

[10] Fisheries Department, West Godavari District, Andhra Pradesh, 2020.

[11] Rodgers, JH Jr., Dunn, A. Developing design guidelines for constructed wetlands to remove pesticides from agricultural runoff. Ecological Engineering. 1992, 1, pp:83-95.

[12] Lakatos, G., Kiss, MK., Kiss, M., Juhasz, P. Application of constructed wetlands for wastewater treatment in Hungary. 1997. Water Science and Technology. 35 (5), pp: 331-336.

[13] Kadlec. R. H..Knight. R. L..Vymazal.J.. Brix. H.. Cooper. P..\&Haberl. R. Constructed wetlands for pollution control. Scientific and technical report no. 8. London: IWA. 2000.

[14] Haberl. H. Erb. K. H. Krausmann. F. Adensam. H \& Schulz. N. Land-use change and socioeconomic metabolism in Austria. part II: Land-use scenarios for 2020. Land Use Policy. 2003. 20(1): pp:21-39

[15] Scholz. M. Wetland systems to control urban runoff. Amsterdam Elsevier. 2006

[16] Vymazal. J. Removal of nutrients in various types of constructed wetlands. Science of the Total Environment. 2007. 380(1-2), pp:48-65.

[17] Carty. A..Scholz. M.. Heal. K..Gouriveau. F..\& Mustafa. A. The Universal design. operation and maintenance guidelines for Farm Constructed Wetlands (FCW) in temperate climates Bioresource Technology, 2008, 99(15), pp:6780 - 6792.

[18] Hu, J.; Qiao, Y.; Zhou, L.; Li, S. Spatiotemporal distributions of nutrients in the downstream from Gezhouba Dam in Yangtze River, China. Environ. Sci. Pollut. Res. 2012, 19, pp: 2849-2859.

[19] Porrello S, Ferrari G, Lenzi M, Persia E. Ammonia variations in phytotreatment ponds of land-based fish farm wastewater. Aquaculture. 2003, 219, pp:485-494

[20] Van Rijn J. Thepotentialfor integrated biological treatmentsystems in recirculating fish culture - a review. Aquaculture. 1996, 139, pp:181-201.

[21] Konnerup D, Trang NTD, Brix H. Treatment of fishpond water by recirculating horizontal and vertical flow constructed wetlands in the tropics. Aquaculture. 2011, 313, pp:57-64

[22] Srivastava J., Gupta A. \& Chandra H. Managing water quality with aquatic macrophytes. Reviews in Environmental Science and Biotechnology. 2008, 7, pp:255-266

[23] Suresh B. \& Ravishankar G.A. Phytoremediation--a novel and promising approach for environmental clean-up. Crit Rev Biotechnol, 2004, 24(2-3), pp:97-124.

[24] Sekhar K.C., Chary N.S., Kamala C.T.. Fractionation studies and bioaccumulation of sediment-bound heavy metals in Kollerulake by edible fish. Environment International. 2004, 29, pp:1001-1008.

[25] APHA. Standard Methods for the Examination of Water and Wastewater. American Public Health Association/American Water Works Association/Water Environment Federation, 21st edition, Washington DC, USA. 2005.

[26] Ribeiro, G.M.; Maia, C.E.; Medeiros, J.F.D. Use of linear regression to estimate the relationship between electrical conductivity and ionic composition of irrigation water. Rev. Bras. Eng. Agric. Ambient. 2005, 9, pp:15-22.

[27] Coldebella, A., Gentelini, A.L., Piana, P.A., Coldebella, P.F., Boscolo, W.R. and Feiden, A. Effluents from fish farming ponds: A view from the perspective of its main components. Sustainability. 2018, 10(1) pp:3.

[28] Campbell, I.C. A biological investigation of an organically polluted urban streams in victoria. Australian journal of marine and fresh water research. 1978, 29, pp:275-291

[29] Kumar, A. \& Gupta, H. P. Bacteriological studies on some sewage-fed wetlands of Jharkhand. In: Ecology of Polluted Waters (Ed. A. Kumar) Ashish Publ. Corporation, New Delhi. 2002, pp:925-936.

[30] Cyrino, J.E.P.; Bicudo, Á.J.D.A.; Sado, R.Y.; Borghesi, R.; Dairik, J.K Fish farming and the environment - the use of environmental friendly feeds in fish culture. Rev. Bras. Zootec. 2010, 39, pp:68-87. 
[31] TamotSadhana and Pratibha Sharma Physico-chemical Status of Upper Lake (Bhopal, India) Water Quality with Special Reference to Phosphate and Nitrate Concentration and Their Impact on Lake Ecosystem, Asian J. Exp. Sci., Vol. 20, No. 1, 2006, pp:151-158.

[32] Ariel ET, Jutta P. Sustainable treatment of aquaculture effluents - what can we learn from the past for the future? Sustainability.2014, 6 , pp:836-856.

[33] Enduta A, Jusoh A, Ali N, Wan Nik WB. Nutrient removal from aquaculture wastewater by vegetable production in aquaponics recirculation system. Desalination Water Treat. 2011. 32, pp:422-430.

[34] Wang XJ, Xia SQ, Chen L, Zhao JF, Renault NJ, Chovelon JM. Nutrients removal from municipal wastewater by chemical precipitation in a moving bed biofilm reactor. Process Biochem. 2006 41, pp:824-828.

[35] Hadad, H.R., Maine M.A.\&Bonetto, C.A. Macrophyte growth in a pilot-scale constructed wetland for industrial wastewater treatment, Chemosphere. 2006, 63, pp:1744-1753.

[36] Zaimoglu, Z. Treatment of campus wastewater by a pilot-scale constructed wetland utilizing Typhalatifolia,Juncusacutus and Iris versicolor, Journal of Environmental Biology. 2006, 27(2), pp:293-298.

[37] Cooper P.F., Job G.D., Green M.B. \&Shutes R.B.E. Reed bed and constructed wetlands for waste water treatment, WRcSwindon, Wiltshire, UK. 1996.

[38] Wijetunga, S., Sandamali, D.H.U.\&Weerasinghe, K.D.N.. Evaluation of efficacy in the treatment of domestic wastewater by different aquatic macrophytes, Journal of Environmental Research and Development. 2009. 4(2), pp:297-309.

[39] Kadlec, R.H. \& Wallace, S. Treatment wetlands.Second edition.CRC Press. Taylor and Francis Group. Boca Raton, FL, accessed on 14-08-2013.

[40] U.S. Environmental Protection Agency. Constructed wetlands treatment of municipal wastewaters design Manual.EPA/625/R-99/010. 2000, Cincinnati, OH.

[41] Wallace, S.D. \& Knight, R.L. Small Scale Constructed Wetland Treatment Systems. Feasibility, Design Criteria, and O\&M Requirements; Water Environ. Res. Foundation: Alexandria, VA, USA. 2006.

[42] Scholz, M., Sadowskia, A.J., Harrington, R. \& Carroll, P. Integrated Constructed Wetlands assessment and design for phosphate removal, Biosystems Engineering, 2006, 97, pp:415-423.

[43] Woltemade, C. Ability of restored wetlands to reduce nitrogen and phosphorus concentrations in agricultural drainage water.Journal of Soil and Water Conservation, 2000, 55, pp:303-309.

[44] Koner, S., Lyatuu, G.B. \&Vermaat J.E. The influence of LemnagibbaL. on the degradation of organic material in duckweed-covered domestic wastewater, Water Research. 1998, 32(10), pp:3092- 3098.

[45] Karathanansis, A.D., Potter, C.L. \& Coyne, M.S. Vegetation effects on fecal bacteria, BOD and suspended solid removal in constructed wetlands treating domestic wastewater. Ecol. Engg. 2013, 20:, pp:157-169.

[46] Kadlec, R.H. Hydrological factors in wetland water treatment. In: Hammer DA (ed) Constructed wetlands for wastewater treatment: municipal, industrial and agricultural. Lewis, Chelsea. 1992, pp :25-29.

[47] Seni K. and Jara S. Comparative study of domestic wastewater treatment efficiencies between facultative ponds and water spinach pond, Water Science and Technology. 1995, 32(3), pp:263-270.

[48] Tu, Y.T., Chiang, P.C.J., Yang, S.H., Chen, C.M., Kao. Application of a constructed wetland system for polluted stream. Remediation, Journal of Hydrology. 2014, 510, pp:70-78.

[49] Yang, L., Chang, H., \& Huang, M. L. Nutrient removal in gravel- and soil-based wetland microcosms with and without vegetation. Ecological Engineering. 2001, 18(1), pp:91-105.

[50] Mustafa, A. Constructed Wetland for Wastewater Treatment and Reuse: A Case Study of Developing Country, International Journal of Environmental Science and Development. 2013, 4(1), pp:20-24.

[51] Stephen, E.M. Comparative effectiveness of engineered wetland system in the treatment of anaerobically pre-treated domestic wastewater, Ecological Engineering. 2004, 23, pp:269-284.

[52] [52]Park, N., Kim, J.H. \& Cho, J. Organic matter, anion, and metal wastewater treatment in Damyang surface-flow constructed wetlands in Korea, Ecological Engineering. 2008, 32, pp:68-71.

[53] Ibekwe, A.M., Lyon, S.R., Leddy, M., Jacobson-Meyers, M. Impact of plant density and microbial composition on water quality from a free water surface constructed wetland, Journal of Applied Microbiology. 2006, pp:921-936.
[54] Mishra, V.K., \&Tripathi, B.D. Concurrent removal and accumulation of heavy metals by the three aquatic macrophytes. Bioresource Technology. 2008, 99(15), pp:7091-7097.

[55] Tripathi S, Tripathi DM, Tripathi BD. Removal of Organic Content and Color from Secondary Treated Wastewater in Reference with Toxic Potential of Ozone DuringOzonation. Hydrol Current Res. 2011, 2(1), pp:1-6.

[56] Kumari, M. \&Tripathi, B.D. Effect of aeration and mixed culture of Eichhorniacrassipes and Salvinianatans on removal of wastewater pollutants. Ecological Engineering, 2014, 62, pp:48-53.

[57] Ramakrishna Rao. S, Bala Prasad. S, Raja Sekhar P. S, Rahiman S.A. Performance Studies on Wastewater Treatment Efficiency of an Artificial Wetland Journal of Environmental Engineering and Technology. 2013, Vol.2 No.3.

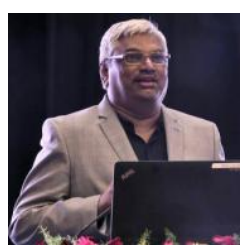

Author Name Qualification Engineering Organization

Visakhapatnam Present Position : Senior Environmental Engineer

P. Ravindra Nadh is working with AP Pollution Control Board since 1988 in various capacities. Trained in University of Ottawa, Canada in various aspects of Pollution Control and Environmental Protection. Has extensive field experience in various aspects of wastewater treatment, emission control equipment and Environmental impact assessment. Currently a research scholar working on Environmental Management Plan for Kolleru Lake in Jawaharlal Nehru Technological University, Kakinada. Earlier publications include studies on variability of Petroleum Hydrocarbons in the industrial effluent discharge influenced coastal region on the Central East Coast of India and Investigations of Physico-chemical parameters and its pollution implications of Kolleru Lake. 